\title{
FOOD SAFETY OF GENETICALLY MODIFIED ORGANISM ACCORDING TO INTERNATIONAL LAW AND ITS IMPLEMENTATION IN INDONESIA
}

\author{
Risa Mahdewi ${ }^{1}$, Desia Rakhma Banjarani ${ }^{2}$ \\ ${ }^{1}$ Kejaksaan Negeri Tanggamus, Indonesia, Email: risamahdewi@gmail.com \\ ${ }^{2}$ Faculty of Law, Universitas Lampung, Indonesia, Email: desiarahma7@ gmail.com
}

Submitted: February 4, 2020; Reviewed: February 19, 2020; Accepted: February 29, 2020

\begin{tabular}{ll}
\hline \multicolumn{1}{c}{ Article Info } & \multicolumn{1}{c}{ Abstract } \\
\hline Keywords: & Modern biotechnology products have provided \\
Food, Safety, Biosafety, GMO & considerable benefits for improving human life and well- \\
being, both in the agriculture, food, industry and human & health sectors, as well as in the environmental field. But \\
DOI: & there are concerns that modern biotechnology products, in \\
10.25041/lajil.v2i1.2031 & addition to providing benefits, also have risks that have \\
& adverse impacts on the conservation and sustainable use of \\
& biodiversity and human health. Therefore, steps need to be \\
& taken, both legally, administratively, and technology to \\
& ensure the level of biological safety. This study aims to \\
& explain and analyze the safety of Genetically Modified \\
& Organism or GMO according to international law and their \\
& implementation in Indonesia. The problem approach used \\
& in this research is normative law (library research). The \\
data used are secondary data obtained from international, & national legal regulations and literature data related to \\
material that supports discussion of the problem. Analysis & of the data used is descriptive qualitative.
\end{tabular}

The results of research on food safety of Genetically Modified Organism or GMO according to international law, are regulations on food safety of genetically engineered products regulated in the Convention on Biological Diversity and the Cartagena Protocol on Biosafety. The laws and regulations governing GMO food in Indonesia are good enough because they have carried out the mandate and did not deviate from the biodiversity convention and Cartagena protocol by passing legislation regulations from the legal level to the decision level of the head of BPOM. It's just that for rules regarding GMO food that is sold in retail, or that is not in the form of packaging, there is still no technical rules that can answer the problems in the field.

\section{A. Introduction}


One of the milestones in the progress of science and technology today besides information technology is the existence of biotechnology. ${ }^{1}$ This technology has an impact on various sectors of human life, ranging from food needs, medicine, health, weapons, industry, and so on. ${ }^{2}$ The development of technology, especially genetic modified technology, ${ }^{3}$ is contributing various benefits to the agricultural sector from food in the world in the past two decades. Through genetic modified plants and food have increased the quality and supply of food to meet the world's growing population needs. ${ }^{4}$ Genetic modified ${ }^{5}$ is covering various traditional processes such as brewing, baking, winemaking, cheese making, the production of various oriental foods such as soy sauce, tempeh and waste treatment which in the process have developed the use of microorganisms since many years ago. ${ }^{6}$

The process of modernization is very broad, with almost no scope and problems, ranging from social, economic, cultural, political aspects, and so on. ${ }^{7}$ Modernization also has an impact on biotechnology products. Modern biotechnology products have provided considerable benefits for improving the lives and well-being of people, both in the agriculture, food, industry, human health sectors, as well as in the environmental field. But there are concerns about modern biotechnology products. Besides providing benefits, they also have risks that have adverse impacts on the conservation and sustainable use of biodiversity and human health. ${ }^{8}$ Therefore, the steps need to be taken, both legally, administratively, and technology to ensure the level of biological safety. For this reason, the United Nations Environment Program (UNEP) Governing Council in 1987 decided to establish an Ad Hoc Working Group consisting of biodiversity experts. $^{9}$

In May 1991, the Ad Hoc Working Group became the Intergovernmental Negotiating Committee (INC) for the Convention on Biological Diversity. INC held a total of seven negotiation sessions from 1991 to 1992. The meeting turned into a conference to adopt the final text of the Convention on Biological Diversity on May 22, $1992 .{ }^{10}$

\footnotetext{
${ }^{1}$ Biotechnology is closely related to biodiversity, this is because biodiversity is a genetic resource of biotechnology, which in its development, the tendency of commercialization, large-scale OHMG production, weak supervision, lack of information and other things become obstacles in the use of biotechnology. Bernhard A. Koch, Economic Loss Caused by Genetically Modified Organisms Liability and Redress for Adventitious Presence of GMOs in Non-GM Crops, (Germany: European Centre of Tort and Insurance Law: 2007), 5.

2 Jeremy Rifkin, The Biotech Century: How Genetic Commerce Will Change The World (London: Phoenix, 1998), 2 .

${ }^{3}$ Genetic modified is the ability to move genes among sexually incompatible organisms, creating new organisms from desirable characteristics. Gerald C. Nelson, Genetically Modified Organisms in Agriculture Economics and Politics (USA: Academic Press, 2001), 7

${ }^{4}$ John E. Smith. Biotechnology (Jakarta: EGC, 1995), 2-3. As write in Indra P Pasaribu, "TINJAUAN HUKUM INTERNASIONAL TERHADAP PERTANGGUNGJAWABAN DAN UPAYA PEMULIHAN (LIABILITY AND REDRESS) ATAS KERUGIAN YANG TIMBUL DARI PERPINDAHAN LINTAS BATAS ORGANISME HASIL MODIFIKASI GENETIK", A Thesis of Department of International Law, Faculty of Law, University of North Sumatra, Medan, (2011), 16.

${ }^{5}$ Genetic modified itself is a process used to create GM seeds. Food plants, and the food they produce, are technologies used to isolate genes from one organism, manipulate them in the laboratory, and inject them into other organisms. Mark A. Pollack, When Cooperation Fails The International Law and Politics of Genetically Modified Foods (New York: Oxford University Press, 2009), 9.

${ }^{6}$ Knut J. Heller, Genetically Engineered Food Methods and Detection (Germany: Bibliographic Information Published: 2003), 62.

${ }^{7}$ Ricco Andreas, Bambang Suryadi, "NILAI ISLAM DAN PANCASILA: PENGARUH GLOBALISASI DAN MODERNISASI DALAM PEMBANGUNAN SISTEM HUKUM DI INDONESIA", Nizham 07, no. 1 (2019): 80-97, 82.

8 http://lawwatchforum.com/wp/perlindungn-hukum-terhadap-dampak-perkembangan-produk-bioteknologi/, Accessed on June 2, 2020.

${ }^{9}$ Ibid.

${ }^{10}$ Terje Traavik and Lim Li Ching, Biosafety First-Holistic Approaches to Risk and Uncertainty in Genetic Engineering and Genetically Modified Organism (Third World Network and Genok, 2009), 389.
} 
The Convention on Biological Diversity was born as a manifestation of humanity's concern over the diminishing value of biodiversity caused by the rapid rate of biodiversity damage and the need for the world community to integrate all safeguards for the survival of nature and humankind furthermore. ${ }^{11}$ Through this convention, the world community recognizes that biodiversity is a common concern of humankind, and is an inseparable part of the development process. $^{12}$

As a follow-up the safety of Genetically Modified Organisms (GMO) products and as implement the provisions of the Convention on Biological Diversity, the international community has agreed on a protocol for $\mathrm{KKH}$ which came to be known as the Cartagena Protocol on Biosafety to the Convention on Biological Diversity in 2000. ${ }^{13}$

The Cartagena Protocol was created to ensure an adequate level of protection in the area of transfer, treatment and safe use of living modified organisms derived from modern biotechnology, and specifically focuses on transboundary movements. This causes regulations to be held regarding impacts on the environment and human health, including marketing and releasing products to the environment. ${ }^{14}$

Indonesia, which is one of the mega diversity countries, is located in the biodiversity distribution path of the continents of Asia (Java, Sumatra and Kalimantan) and Australia (Papua), and in the Wallace line transition zone (Sulawesi, Maluku and Nusa Tenggara). ${ }^{15}$ Not only is it known as a megadiverse country, but Indonesia is also known as one of the countries with a high level of biodiversity loss in the world. ${ }^{16}$

Be aware of the richness of biodiversity owned, ${ }^{17}$ Indonesia ratified the Convention on Biological Diversity by passing Law Number 5 of 1994 concerning Ratification of the United Nations Convention on Biological Diversity. As well as ratifying the Cartagena Protocol is by Law Number 21 of 2004 concerning Ratification Cartagena Protocol on Biosafety to The Convention on Biological Diversity. ${ }^{18}$

Based on the above background, the issue to be discussed in this research is how to regulate food safety of genetically modified organism according to international law and their implementation in Indonesia. The research method used is a normative legal research method, which means only legal research norms that have relevance with GMO and biosafety. ${ }^{19}$ The

${ }^{11}$ http://biogen.litbang.pertanian.go.id/index.php/2008/06/konvensi-keanekaragaman-hayati/, Accessed on June 2,2020 .

12 http://www.industry.gov.au/resource/Documents/LPSDP/LPSDP-BiodiversityIndo.pdf, Accessed on June 1, 2020.

13 Ruth Mackenzie, An Explanatory Guide to the Cartagena Protocol on Biosafety (Switzerland: IUCN Environmental Law Centre, 2003), 17.

14 Badan Pengawas Obat dan Makanan, Pangan Produk Rekayasa Genetik, http://www.pom.go.id/mobile/index.php/view/berita/162/Pangan-Produk-Rekayasa-Genetik.html, Accessed on June 1, 2020.

15 Indonesia Biosafety Clearing House, Protokol Cartagena. http://indonesiabch.or.id/protokol-cartagena/, Accessed on June 1, 2020.

16 http://www.pelatihanlingkungan.com/wp-content/uploads/2015/05/Sambutan-Menteri-hari-Kehati-2015.pdf, Accessed on June 1, 2020.

${ }^{17}$ Biodiversity is all life on earth which includes plants, animals, fungi and microorganisms, as well as the various genetic material they contain and the diversity of ecological systems in which they live, including the abundance and genetic diversity of organisms originating from all habitats, whether on land, sea or other water systems. Social Economic Environmental, Praktek Unggulan Program Pembangunan Berkelanjutan Untuk Industri Pertambangan, (Australia: Global Village Translations, 2007), 4.

18 http://www.menlh.go.id/pengesahan-cartagena-protocol-on-biosafety-to-the-convention-on-biologicaldiversity/, Accessed on June 1, 2020.

19 Ahmad Syarifudin, "IMPLIKASI ADANYA UPAYA HUKUM TERHADAP PUTUSAN BAWASLU TENTANG PELANGGARAN ADMINISTRATIF PEMILU PROBLEMATIC OF SETTLEMENT OF ELECTION ADMINISTRATIVE OF VIOLATION'S," Cepalo 4, no. 1 (2020): 1-12, 4, DOI: 10.25041/cepalo.v4no1.1897. 
data obtained are secondary data from literary sources such as literature, articles and internet sites.

\section{B. Discussion}

\section{Food Safety of Genetically Modified Organism According to International Law}

\section{a. Convention on Biological Diversity}

Convention on biodiversity ${ }^{20}$ as stipulated in its provisions is the conservation of biodiversity, the sustainable use of its components and the sharing of benefits resulting from the efficient and equitable utilization of genetic resources, including through adequate access to genetic resources and with the appropriate transfer of technology, and by taking into account all rights to those resources and technology, as well as with adequate funding.

Biodiversity conservation itself is defined as the management of living natural resources, the use of which is carried out wisely to ensure the sustainability of its supply while maintaining and improving the quality of diversity and its value. ${ }^{21}$

The use of biodiversity must not damage the environment, interfere with the sustainability of biodiversity, and endanger human health. This means that special methods are needed for security in the implementation of the use of biological diversity, both traditional and technological uses (one of which is biotechnology / genetic modification). Biological safety is essential to apply, this is because biodiversity covers all aspects of life on earth, so that security and sustainability of biodiversity must be maintained so as not to damage the environment, disrupt the sustainability of biodiversity and endanger human health.

The use of biodiversity that is not concerned with security aspects for human health is a scary thing for consumers, especially for the use of biodiversity by technological processes, namely by biotechnology, or what we call genetic engineering. Using genetic engineering technology will change some of the genes in the organism, which will be consumed by humans so that it can endanger human health. Therefore the discussion on human food (food) is also included in the security of the use of biodiversity (biodiversity) which must be regulated and carried out using a precautionary approach.

In order to achieve this, the parties to this convention are required to enact legislative, administrative and policy measures in accordance with the aim that the parties, especially developing countries, which provide genetic resources are given access to the transfer of technology used to utilize these resources. ${ }^{22}$

Biological safety ${ }^{23}$ covers food safety, feed security, and environmental security. Biosafety is regulated for the first time in the Cartagena Protocol on Biosafety, whereby the protocol is made based on the mandate of the Convention on Biodiversity which says that:

"The parties must consider the need for protocols and models that determine the appropriate procedures including specifically informed consent, in the area of transfer, safe handling and

\footnotetext{
${ }^{20}$ The convention was adopted as an international agreement in 1992 at the Earth Summit forum in Rio de Jeneiro, Brazil. At present it has been signed by 168 countries and ratified by 157 countries, out of 198 countries that are members. The United States is the only major country that has not yet ratified it. Jurnal Bumi, Konvensi Keanekaragaman Hayati. https://jurnalbumi.com/konvensi-keanekaragaman-hayati/, Accessed on February 1, 2020 .

${ }^{21}$ Article 1 of Law Number 5 of 1990 concerning Conservation of Living Natural Resources and Their Ecosystems.

${ }^{22}$ Article 16 Paragraph (3) Convention on Biological Diversity.

${ }^{23}$ Biosafety is a discipline in the handling and containment system of infectious microorganisms and hazardous biological substances. See also Online News, Directorate of Research and Innovation, Bogor Agricultural University, 2014, Biosafety and Biosecurity Training for Laboratory Assistants. http://dri.ipb.ac.id/pelatihanbiosafety-dan-biosecurity-bagi-laboran/, Accessed on June 1, 2020.
} 
use of modified biotechnology organisms, which may have adverse effects on the conservation and sustainable use. Biodiversity". ${ }^{24}$

The Biosafety Convention or KKH governs the provisions regarding the security of the application of modern biotechnology, namely in clauses of Article 8 letter (g), Article 16, Article 19 paragraph (3) and paragraph (4). It mandates the establishment of a protocol to regulate cross-border movement, handling and utilization of Organisms Results of Genetic Modification (OHMG) as a product of modern biotechnology. Based on the mandate of these articles, the KKH parties began to negotiate the Protocol on Biosafety since 1995. It was only adopted in 2000 at the fifth session of the KKH Conference of the Parties in Nairobi. ${ }^{25}$

\section{b. Cartagena Ptotocol on Biosafety}

Cartagena Protocol ${ }^{26}$ is a protocol on the Convention on Biological Diversity, where the Convention on Biological Diversity $(\mathrm{KKH})$ reveals in Article 16 (access and transfer of technology) that access and transfer of modern biotechnology is an important element for achieving the objectives of the KKH. In the first two paragraphs of Article 19 (handling biotechnology and the distribution of benefits) that parties must increase and develop priority access to the results and benefits arising from biotechnology. ${ }^{27}$

\section{1) Advance Informed Agreements}

Prior notification is a procedure that must be applied by parties carrying out cross-border OHMG transfers deliberately introduced into the environment by the importer at the time of the first shipment to ensure that the recipient country has the opportunity and capacity to assess GMO risks. ${ }^{28}$

\section{2) Procedure for Direct Use of GMO}

This procedure applies to GMO which will be used directly as food, feed, or processed materials, provided that the decision-maker (the importer) is required to provide information at least as stated in Attachment II to the Biosafety Clearing-House in within 15 days of the decision being made, by national regulations consistent with the protocol's objectives. ${ }^{29}$

\section{3) Risk Assessment}

Risk assessment is the application of the precautionary principle undertaken to make decisions on the inclusion of GMO, which will be introduced to the environment. The risk assessment must be based on the completeness of the minimum information in the notification as contained in Appendix I and other scientific evidence to identify and evaluate the possible impacts of GMO on the conservation and sustainable use of biodiversity as well as risks to human health. ${ }^{30}$

\section{4) Risk Management}

\footnotetext{
${ }^{24}$ Article 19 paragraph (3) of the Convention on Biological Diversity.

${ }^{25} \mathrm{http}$ ://indonesiabch.or.id/protokol-cartagena/, Accessed on June 1, 2020.

${ }^{26}$ The Cartagena Protocol is intended to create uniform international procedures for regulating the safe movement of modified organisms. At the protocol center there is a further information agreement. Procedures that will apply prior to intentional transboundary movement of transgenic organisms for deliberate introduction into the importer's environment. Han Somsen, The Regulatory Challenge of Biotechnology Human Genetics, Food and Patents (UK: Edward Elgar Publishing Limited, 2007), 105.

${ }^{27} \mathrm{http}$ ://www.prri.net/id/cartagena-protocol-biosafety/, Accessed on June 1, 2020.

${ }^{28}$ Article 7 of the Cartagena Protocol on Biosafety.

${ }^{29}$ Article 11 of the Cartagena Protocol on Biosafety.

${ }^{30}$ Article 15 of the Cartagena Protocol on Biosafety.
} 
Risk management is a follow-up to the implementation of a risk assessment that includes the establishment of appropriate mechanisms, steps and strategies for managing, managing and controlling the risks identified in the risk assessment. The obligation arising from the application of risk management to these parties is to establish and implement a regulatory system with sufficient capacity to manage and control these risks. ${ }^{31}$

\section{5) Accidental Transboundary Movements and Emergency Measures}

Accidental cross-border movements are GMO movements that occur outside the agreement of the importing and exporting parties. States parties must take steps through the notification to the Biosafety Clearing-House if a possible accident occurs and notify the contact points that can be contacted. In order to minimize significant adverse effects on the conservation and sustainable use of biodiversity, taking into account also risks to human health, each party in whose jurisdiction releases genetically modified organisms must immediately consult with a disadvantaged or potentially disadvantaged country so that they can decide on an appropriate response and take the necessary initial steps of action, including emergency measures. ${ }^{32}$

\section{6) Handling, Transportation, Packaging and Utilization}

Handling, transporting, packaging, and utilizing GMO intended for limited use clearly shows their identity as GMO and specifies any requirements for safe handling, storage, transportation and use, contact for further information, including names and the addresses of individuals and institutions to which the modified organism is transmitted. Regulation of GMO handling, transport, packaging and utilization is part of efforts to ensure the safety of GMO development in accordance with the requirements of relevant international standards. ${ }^{33}$

\section{7) Biosafety Clearing House}

The Biosafety Clearing-House is a body formed by the parties under Article 20 of the Cartagena Protocol to facilitate the exchange of information in the scientific, technical, environmental and regulatory aspects of GMO in implementing the protocol.

\section{8) Capacity Development}

The capacity building aims to develop and strengthen human resources and institutional capacity of developing countries in implementing the Cartagena protocol. Article 22 of the Cartagena Protocol regulates capacity development which requires cooperation taking into account the needs, conditions and capabilities of developing countries and countries undergoing economic transition. Cooperation assistance can be in the form of scientific and technical training, transfer of technology and skills, and financial assistance. This capacity building is expected to help developing countries with a lack of human resources who are experts in the field of biotechnology. As well as funds in training and research in biotechnology, so that the development, application and use of biotechnology on biodiversity do not damage the environment, disrupt the sustainability of biodiversity and endanger health human. Especially on food and feed of genetically modified products will be consumed by living things.

\section{9) Obligations of the Parties to the Community}

Communities as part of the food chain that will consume genetically engineered food products, or instead become producers of genetically engineered food products, are required to know how to use GMO properly, as well as the safe transfer, handling and use of GMO.

\footnotetext{
${ }^{31}$ Article 16 of the Cartagena Protocol on Biosafety.

${ }^{32}$ Article 17 of the Cartagena Protocol on Biosafety.

${ }^{33}$ Article 18 of the Cartagena Protocol on Biosafety.
} 
Therefore, the parties in this protocol must provide information, training, and provide consultation to the community in their respective regions. ${ }^{34}$

The Cartagena Protocol only provides basic guidelines in the process of moving GMOs across countries without providing detailed regulations regarding ownership rights, permits for use and commercialization, monitoring, field testing, or compensation/responsibility in the event of negative impacts. Detailed regulations governing all these procedures are left to the regulations of each country which must be based on the contents of the Cartagena protocol, this is in accordance with the mandate of Article 2 of the Cartagena Protocol which states that each party is obliged to take legal, administrative and other actions that are necessary and appropriate to carry out its obligations under this protocol.

The regulation of food safety of genetically engineered products according to international law regulated in the Convention on Biological Diversity and the Cartagena Protocol. Where the two rules only provide general rules on how the use of biodiversity and biodiversity which includes food security, but for implementing rules, sovereignty is given to the parties to regulate themselves according to the needs and policies that apply in each country while not contradicting with the rules in the conventions and protocols.

\section{Implementation of Food Safety of Genetically Modified Organism in Indonesia}

\section{a. Law Number 7 of 1996 concerning Food (Updated to Law Number 18 of 2012 concerning Food)}

In detail, the definition of GMO food products is anything comes from biological sources of the agricultural, plantation, forestry, fishery, livestock, aquatic, and water products, whether processed or unprocessed that are intended as food or drinks for human consumption, including additives food, food raw materials, and other materials used in the process of preparing, processing and/or making food or drinks produced from genetic engineering processes.

Food safety is organized to keep food safe, hygienic, quality, nutritious, and not contrary to the religion, beliefs and culture of the community. Food safety is intended to prevent the possibility of biological, chemical and other contaminants that can disturb, harm and endanger human health. ${ }^{35}$

The Government and Local Governments ensure the realization of the implementation of food security in each food chain in an integrated manner. As an executor, the government sets food safety norms, standards, procedures and criteria whereby farmers, fishermen, fish growers, and food businesses must implement food safety norms, standards, procedures and criteria that have been set. The implementation of the norms, standards, procedures and criteria for food safety will be carried out in stages based on the type of food and the scale of the food business. In this case, the Government and/or Regional Government must develop and supervise the implementation of food safety norms, standards, procedures and criteria. ${ }^{36}$ The implementation of food safety is carried out through a. Food sanitation; b. regulation of food additives; c. regulation of PRG food; d. regulation of food irradiation; e. setting food packaging standards; f. granting guarantees for food safety and food quality; and g. halal product guarantee for those who are required.

One of the implementations of food safety is carried out through the regulation of genetically engineered food products, where food produced from genetic engineering must obtain food safety approval before being circulated. Food production processes are prohibited from using raw materials, food additives, and/or other materials produced from food genetic

\footnotetext{
${ }^{34}$ Article 23 of the Cartagena Protocol on Biosafety.

${ }^{35}$ Article 67 of Law Number 18 Year 2012 concerning Food.

${ }^{36}$ Article 68 of Law Number 18 Year 2012 concerning Food.
} 
engineering that have not yet received food safety approval before being circulated. The government gave food safety approval.

The government establishes the requirements and principles of research, development, and utilization of food genetic engineering methods in food production activities or processes. It stipulates the requirements for testing food produced from food genetic engineering.

\section{b. Law Number 36 of 2009 concerning Health}

Law Number 36 of 2009 concerning Health in the sixteenth part regulates the security of food and beverages which will be circulated in Indonesia. It is said every person and/or legal entity that manufactures, processes. It distributes food and beverages which are foods and beverages produced from genetically engineered technology that is circulated must ensure that it is safe for humans, animals that humans eat, and the environment. ${ }^{37}$ The explanation above clearly states humans will consume food or drinks, whether derived from plants or animals resulted by GMO. It must be safe for human health and the environment, meaning that the food to be circulated and consumed must be safe and do not adversely affect human health or the environment.

The ways of producing and promoting genetically engineered food and beverage products must provide true information about these products, which will not deceive and cover up the truth that food and beverage products that are produced and promoted are genetically engineered products. Genetically engineered food and feed must not adversely affect human health, animal health, or the environment or mislead consumers, ${ }^{38}$ as stated in article 110 of this law which states that:

"Any person and/or legal entity manufactures promote food and beverage products and/or which is treated as processed food and beverage technology is prohibited from using words that are deceiving and/or that are accompanied by claims that cannot be verified".

\section{c. Government Regulation Number 69 of 1999 concerning Food Labels and Advertisements}

One of the goals of regulating, fostering and controlling food is the creation of honest and responsible food trade. Food labels and advertisements are facilities in food trading activities that have an important meaning, so they need to be regulated and controlled, so that information about food delivered to the public is true and not misleading.

Labels for genetically engineered foods must be labelled GMO, if genetically engineered food is an ingredient used in a food product, on the label it is sufficient to include information about genetically engineered food on ingredients which are genetically engineered food. In addition to the inclusion of writing on the label can be included a special logo of genetically modified food. ${ }^{39}$

\section{d. Government Regulation Number 21 of 2005 concerning Biological Safety of Genetically Modified Organism jo Government Regulation Number 28 of 2004 concerning Quality Safety and Food Nutrition}

This government regulation is intended to realize environmental security, food security and/or security of GMO feed and its use in agriculture, fisheries, forestry, industry, environment, and non-pharmaceutical health. The improvement of the effectiveness of GMO for people's welfare is based on the principles of health and management of biological

\footnotetext{
${ }^{37}$ Article 109 of Law Number 36 Year 2009 concerning Health.

${ }^{38}$ Knut J. Heller, Genetically Engineered Food Methods and Detection Second, Updated and Enlarged Edition. (Germany: Bibliographic information published, 2006), 135.

${ }^{39}$ Article 35 Government Regulation Number 69 of 1999 concerning Food Labels and Advertisements.
} 
resources, consumer protection, legal certainty and certainty in conducting business. ${ }^{40}$ Food safety of GMO is the conditions and efforts to prevent the possibility of adverse impacts and endanger human health, due to the process of production, preparation, storage, distribution and utilization of genetically modified food products. ${ }^{41}$

Genetically modified products or modified organisms, hereinafter abbreviated as GMO, are living organisms, their parts and/or their processed products which have a new genetic makeup from the application of modern biotechnology. Types of GMO include a. GMO animals, materials from GMO animals, and their processed products; b. GMO fish, ingredients from GMO fish, and their processed products; c. GMO plants, materials from GMO plants, and their processed products; d. GMO microorganisms, materials from GMO microorganisms, and their processed products. The government regulation regulates the safety and quality of food for GMO in Article 14 which states that "everyone who produces food or uses raw materials, food additives, and / or other auxiliary materials in activities or processes of food production resulting from the process genetic engineering must first check the safety of the food before it is distributed". The food safety inspection of GMO is carried out by a commission that handles food safety of genetically engineered products. Genetic information, including general descriptions of genetically modified food products and descriptions of hosts and their use as food; a. description of donor organisms; b. description of genetic modification; c. characterization of genetic modification; d. food safety information, including substantial equivalence, changes in nutritional value, allergens and toxicity.

\section{e. Government Regulation Number 102 the Year 2000 concerning National Standardization}

Standardization is the process of formulating, establishing, implementing and revising standards, which is carried out in an orderly manner and in collaboration with all parties. The scope of national standardization covers all activities related to technical metrology, standards, testing and quality. ${ }^{42}$ Judging from the scope of national standardization which includes standards, testing and quality, it can be interpreted that national standardization also includes standards, testing and food quality that will circulate in Indonesia, both domestic and imported food. This is in accordance with Article 19 paragraph (1) which reads:

"Indonesian national standards that are enacted compulsorily apply equally to both goods and or services of domestic production and to imported goods and or services". One of the goals of the application of national standardization is to increase protection for consumers, business people, workers, and other communities both for safety, security, health and preservation of environmental functions. ${ }^{43}$ From the goal of implementing national standardization, we can know that safety, security and public health are the main priorities along with environmental preservation. This also applies in the application of national standards for food, where food must be good for the safety, security and health of the community/people who produce and consume it.

\section{f. Presidential Regulation Number 53 the Year 2014 Amendment to Presidential Regulation Number 39 the Year 2010 concerning the Commission on Biosafety of Genetically Modified Organism}

\footnotetext{
${ }^{40}$ Article 2 Government Regulation Number 21 of 2005 concerning Biological Safety of Genetically Modified Organism.

41 Article 1 Paragraph (3) Government Regulation Number 21 Year 2005 concerning Biological Safety of Genetically Modified Organism.

${ }^{42}$ Article 2 Government Regulation Number 102 of 2000 concerning National Standardization.

${ }^{43}$ Article 3 paragraph (1) Government Regulation Number 102 of 2000 concerning National Standardization.
} 
The Commission on Biological Safety of Genetically Engineered Products (KKH PRG) is a non-structural institution that is under and is responsible to the President. KKH PRG has the following tasks: ${ }^{44}$

1) Provide biological safety recommendations to the Minister of the Environment, the authorized Minister, and the Head of the authorized Non-Ministry Government Institution as a basis for consideration for the issuance of GMO release and/or distribution decisions;

2) Provide certificates of the results of tests of environmental safety, food security and/or feed security to the Minister of the Environment, the authorized Minister, and the Head of the authorized Non-Ministry Government Institution as a basis for consideration of issuing decisions on the release and/or circulation of the GMO;

3) Provide advice and considerations to the Minister of Environment, the authorized Minister, and the Head of the Non-ministerial Government Institution authorized in the stipulation of guidelines for impact monitoring, risk management and withdrawal of GMO from circulation; and

4) Assist the Minister of Environment, the Minister who is authorized, and the Head of the Non-Ministry Government Institution authorized to carry out oversight of the import and use of the GMO as well as the examination and verification of the truth of reports of the negative impacts of the PRG.

KKH GMO functions:

1) Formulation of materials for the preparation of guidelines for the assessment of environmental safety, food security, as well as monitoring the use of GMO;

2) The assignment of the Minister of the Environment, the Minister who is authorized, and the Head of the Non-Ministry Government Institution authorized to carry out a technical assessment and/or evaluation of the application for environmental safety, food security, and/or food security to release and/or circulate the GMO;

3) Providing relevant information services on the implementation of environmental security, food security in the use of GMO through the Biosafety Clearing-House, hereinafter abbreviated BKKH;

4) Management of information on the assessment of environmental safety, food safety and/or food security through BKKH;

5) Provision of environmental safety recommendations to the Minister of Environment, food security, and/or feed security to the authorized Minister and the Head of the Non-Ministerial Government Institution authorized for the purpose of releasing and / or circulating the GMO, both originating from abroad or from within the country;

6) Providing recommendations for control and mitigation in the event of a negative impact on the release, distribution and/ $r$ use of the PRG to the Minister of the Environment, the authorized Minister, and the Head of the authorized Non-Ministry Government Institution;

7) The assignment of the Minister of the Environment, the authorized Minister, and the Head of the Non-ministerial Government Institution authorized to carry out the examination and verification of reports on the emergence of negative impacts on the environment, human health, and/or animal health caused by release, distribution, and/or the use of GMO;

8) Implementation of cooperation and consultation with various institutions both inside and outside the country in environmental safety, food security;

9) Organizing evaluation and testing of environmental safety, food security, due to the use of PRG;

\footnotetext{
${ }^{44}$ Article 6 Presidential Regulation Number 39 of 2010 concerning the Biosafety Commission for Genetically Modified Organism.
} 
10) Providing input to the Minister of the Environment, the authorized Minister, and the Head of the Non-Ministerial Government Institution authorized in the establishment of guidelines for monitoring and impacting GMO risks; and

11) Providing input to the Minister of Environment, the authorized Minister, and the Head of the Non-ministerial Government Institution authorized in the establishment of PRG withdrawal procedures that harm the environment, human health, and/or animal health. ${ }^{45}$

\section{g. Decree of the Minister of Maritime Affairs and Fisheries Number 52a/Kepmen- Kp/2013 concerning Requirements for Quality Assurance and Safety of Fishery Products in the Production, Processing and Distribution Process}

This ministerial decree is set with the intent as a guideline or reference for business actors in the field of fisheries to apply the quality assurance requirements and safety of fishery products in the production. Processing and distribution processes to obtain fishery products that meet the quality assurance and safety of fishery products that do not endanger human health. ${ }^{46}$

Business actors as part of food distribution in Indonesia, in this case, fishery food products must meet the quality assurance and food safety requirements in terms of production, processing and distribution to the public. The quality assurance system requirements for businesses in the fishery sector in implementing a quality assurance system must be: ${ }^{47}$ a) meet the hygiene requirements in accordance with the requirements; b) applying requirements in preventing biological, chemical and physical hazards to fishery products that are processed according to standards and regulations in accordance with product specifications; c) has the program / procedure needed to fulfill the requirements stipulated in this ministerial decree; d) implementing temperature control requirements by maintaining a cold chain of fishery products or in accordance with product specifications; e) collaborate with competent authorities to enable quality control officers to exercise control in accordance with applicable regulations; f) ensure that employees who handle fishery products have been supervised and directed and / or trained on the requirements and application of food sanitation and hygiene in accordance with activities at their workplace; g) ensure that employees are able and responsible for developing and maintaining required procedures; and $\mathrm{h}$ ) ensure that employees who handle fishery products are not suffering or as carriers of certain diseases that have the potential to cause contamination of fishery products.

h. Regulation of the Head of Drug and Food Supervisory Agency Number 19 of 2016 concerning Amendment to the Regulation of the Head of the Drug and Food Supervisory Agency Number Hk.03.1.23.03.12.1563 of 2012 concerning Guidelines for the Assessment of Safety of Genetically Modified Organism

Genetically Modified Organism food products both GMO food produced domestically or imported into the territory of Indonesia, before being circulated must first be assessed for GMO food safety. PRG Food Safety Assessment is carried out by the Biodiversity Product Biodiversity Commission (KKH GMO) in the context of providing recommendations to the head of BPOM, where the assessment is carried out in accordance with the guidelines for GMO

\footnotetext{
45 Article 7 Presidential Regulation Number 39 of 2010 concerning the Biosafety Commission for Genetically Modified Organism.

${ }^{46}$ Chapter I purposes and objectives of the Decree of the Minister of Maritime Affairs and Fisheries Number 52a / Kepmen-Kp / 2013 concerning Requirements of Quality Assurance and Safety of Fishery Products in the Production, Processing and Distribution Process.

${ }^{47}$ Chapter II Requirements for guaranteeing quality and safety of fishery products Decree of the Minister of Maritime Affairs and Fisheries Number 52a/Kepmen-Kp/2013 concerning Requirements for Quality Assurance and Safety of Fishery Products in the Production, Processing and Distribution Process.
} 
food safety assessment. ${ }^{48}$ It is excluded for GMO processing aid which is used in food products and does not contain GMO DNA and/or PRG protein. The issuance of a GMO food distribution permit is carried out based on a recommendation from the KKG GMO to the head of BPOM which contains the decision to issue a permit or rejection of a GMO food distribution permit. The decision on the PRG food distribution permit is stated or used as a GMO food safety certificate in the context of overseeing the GMO food circulation.

\section{i. Regulation of the Head of the Drug and Food Supervisory Agency Number Hk.03.1.23.03.12.1564 of 2012 concerning Supervision of Food Labeling of Genetically Modified Organism}

GMO food that will be circulated in a packed condition, the label must contain information in the form of writing GENETIC MODIFIED ORGANISM. ${ }^{49}$ The article is included if the food contains at least 5 (five) per cent of GMO food, based on the percentage of the GMO Deoxyribonucleic Acid (DNA) content of the non-GMO Deoxyribonucleic Acid content. If the food contains more than 1 (one) GMO food, the percentage of the content is carried out for each GMO food. ${ }^{50}$

Foods that use 1 (one) GMO food as a single ingredient are listed after writing the name of the type of food on the main part of the label. If food using GMO food is listed after writing the name of the food ingredient concerned in the list of ingredients used the font size for writing must be the same as the letter size of the name of the type of food or the name of the food ingredient. ${ }^{51}$

GMO food that is traded in bulk or in an unpackaged condition must be given clear information that the food is GMO food that is placed in such a way that it is easily visible and must be in a container or close to the container where the food is sold ${ }^{52}$ The problem that occurs is the difficulty of controlling bulk or unregistered foods such as tempeh that are wrapped in such a way without writing down that the food has gone through a genetic modifies organism.

Implementation of food safety arrangements in Indonesia for the ratification of the Convention on Biological Diversity with the enactment of Law Number 5 of 1994 and Law Number 24 of 2004 concerning Ratification of the Cartagena Protocol contained in several laws and regulations as a follow up to the international rules which provide sovereignty in each country to make implementing regulations in accordance with the needs and policies in force in the country which of course remains in accordance with these international rules. The laws and regulations governing GMO food in Indonesia are good enough because they have carried out the mandate and did not deviate from the biodiversity convention and Cartagena protocol by ratifying the legislation regarding GM food from the legal level to the decision level of the head of BPOM. It's just that for rules regarding GMO food that is sold in bulk, or that is not in the form of packaging, there is still no technical rules that can answer the problem in the field.

\section{Conclusions}

\footnotetext{
${ }^{48}$ Article 3 Regulation of the Head of the Drug and Food Supervisory Agency Number 19 of 2016 concerning Amendment to the Regulation of the Head of the Drug and Food Supervisory Agency Number Hk.03.1.23.03.12.1563 of 2012 concerning Guidelines for the Assessment of Safety of Genetically Modified Organism.

${ }^{49}$ Article 5 Regulation of the Head of the Drug and Food Control Agency Number Hk.03.1.23.03.12.1564 of 2012 concerning Supervision of Food Labeling of Genetically Modified Organism.

${ }^{50}$ Article 7 Regulation of the Head of the Drug and Food Control Agency Number Hk.03.1.23.03.12.1564 of 2012 concerning Supervision of Food Labeling of Genetically Modified Organism.

${ }^{51}$ Article 8 Regulation of the Head of the Drug and Food Control Agency Number Hk.03.1.23.03.12.1564 of 2012 concerning Supervision of Food Labeling of Genetically Modified Organism.

${ }^{52}$ Article 6 Regulation of the Head of the Drug and Food Control Agency Number Hk.03.1.23.03.12.1564 of 2012 concerning Supervision of Food Labeling of Genetically Modified Organism.
} 
Regulation of food security for genetically modified organism according to international law is regulated in the Convention on Biological Diversity and the Cartagena Protocol. However, these regulations only provide general rules on how to use biodiversity, which includes food safety. In its implementing regulations, the regulation gives sovereignty to state parties to contain their regulations that are in accordance with the needs that apply in each country, as long as they do not conflict with the rules contained in the conventions and protocols. The laws and government regulation about PRG food in Indonesia are good enough because they have carried out the mandate and did not deviate from the biodiversity convention and Cartagena protocol by passing legislation regulations from the legal level to the decision level of the head of BPOM. Regarding the rules regarding PRG food sold in retail, or not in the form of packaging, there is still no technical regulation that can answer the problems in the field. In addition, there is a lot of circulation of PRG food, but it is not in accordance with the requirements for labelling, national standardization, and good production methods. So, it takes many parties, such as the government check directly to the field, producers must be aware of the importance of maintaining their products so as not to endanger human health and the environment, and consumers must be smart in choosing the food they consume.

\section{Suggestion}

Based on the conclusions, suggestions can be made for additional protocols and rules to discuss in more detail the food of a genetically modified organism. Then with the existence of a special international body or organization that handles in the field of a genetically modified organism that regulates and standardizes the food of genetically modified organism as a reference for countries in making national rules. The needs for formulation and ratification of laws and regulations governing food that is sold in retail, and food that has not been in the form of packaging which is sold freely in the community. 
A. Journal and Thesis

\section{References}

Andreas, Ricco., Suryadi, Bambang. "NILAI ISLAM DAN PANCASILA: PENGARUH GLOBALISASI DAN MODERNISASI DALAM PEMBANGUNAN SISTEM HUKUM DI INDONESIA". NIZHAM 07, no. 1, 2019: 80-97.

Pasaribu, Indra P. "TINJAUAN HUKUM INTERNASIONAL TERHADAP PERTANGGUNGJAWABAN DAN UPAYA PEMULIHAN (LIABILITY AND REDRESS) ATAS KERUGIAN YANG TIMBUL DARI PERPINDAHAN LINTAS BATAS ORGANISME HASIL MODIFIKASI GENETIK”, A Thesis, Department of International Law, Faculty of Law, University of North Sumatra, Medan, 2011.

Syarifudin, Ahmad. "IMPLIKASI ADANYA UPAYA HUKUM TERHADAP PUTUSAN BAWASLU TENTANG PELANGGARAN ADMINISTRATIF PEMILU PROBLEMATIC OF SETTLEMENT OF ELECTION ADMINISTRATIVE OF VIOLATION'S." Cepalo 4, no. 1, 2020: 1-12, DOI: 10.25041/cepalo.v4no1.1897.

\section{B. Book}

Global Village Translations. Pengelolaan Keanekaragaman Hayati. Jakarta: Persemakmuran Australia, 2007.

Heller, Knut J. Genetically Engineered Food Methods and Detection. Germany: Bibliographic Information Published, 2003.

Heller, Knut J. Genetically Engineered Food Methods and Detection Second, Updated and Enlarged Edition. Germany: Bibliographic Information Published, 2006.

Koch, Bernhard A. Economic Loss Caused by Genetically Modified Organisms Liability and Redress for Adventitious Presence of GMOs in Non-GM Crops. Germany: European Centre of Tort and Insurance Law, 2007.

Mackenzie, Ruth. An Explanatory Guide to the Cartagena Protocol on Biosafety. Switzerland: IUCN Environmental Law Centre, 2003.

Nelson, Gerald C. Genetically Modified Organisms in Agriculture Economics and Politics. USA: Academic Press, 2001.

Pollack, Mark A. When Cooperation Fails The International Law and Politics of Genetically Modified Foods. New York: Oxford University Press, 2009.

Rifkin, Jeremy. The Biotech Century: How Genetic Commerce Will Change The World. London: Phoenix, 1998.

Smith, John E. Biotechnology. Jakarta: EGC, 1995.

Social Economic Environmental. Praktek Unggulan Program Pembangunan Berkelanjutan Untuk Industri Pertambangan. Australia: Social Economic Environmental, 2007.

Somsen, Han. The Regulatory Challenge of Biotechnology Human Genetics, Food and Patents. UK: Edward Elgar Publishing Limited, 2007

Terje Traavik and Lim Li Ching. Biosafety First-Holistic Approaches to Risk and Uncertainty in Genetic Engineering and Genetically Modified Organism. Third World Network and Genok, 2009.

\section{Regulation}

Cartagena Protocol on Biosafety 2003.

Convention on Biological Diversity, 1993.

Decree of the Minister of Maritime Affairs and Fisheries Number 52a/Kepmen-Kp/2013 concerning Requirements for Quality Assurance and Safety of Fishery Products in the Production, Processing and Distribution Process.

Government Regulation Number 102 Year 2000 concerning National Standardization. 
Government Regulation Number 21 Year 2005 concerning Biological Safety of Genetically Modified Organism.

Government Regulation Number 69 of 1999 concerning Food Labels and Advertisements.

Law Number 18 of 2012 concerning Food.

Law Number 36 of 2009 concerning Health.

Law Number 5 of 1990 concerning Conservation of Biological Natural Resources and their Ecosystems.

Presidential Regulation Number 39 of 2010 concerning the Biosafety Commission for Genetically Modified Organism.

Cartagena Protocol Biosafety

Regulation of the Head of Drug and Food Supervisory Agency Number 19 of 2016 concerning Amendment to the Regulation of the Head of the Drug and Food Supervisory Agency Number Hk.03.1.23.03.12.1563 of 2012 concerning Guidelines for the Assessment of Safety of Genetically Modified Organism.

Regulation of the Head of the Drug and Food Supervisory Agency Number Hk.03.1.23.03.12.1564 of 2012 concerning Supervision of Food Labeling of Genetically Modified Organism.

\section{Internet}

http://www.pom.go.id/mobile/index.php/view/berita/162/Pangan-Produk-Rekayasa-

Genetik.html, Accessed on June 08, 2016.

http://biogen.litbang.pertanian.go.id/index.php/2008/06/konvensi-keanekaragaman-hayati/,

Accessed on October 1, 2016.

http://indonesiabch.or.id/protokol-cartagena/, Accessed on October 3, 2017.

https://jurnalbumi.com/konvensi-keanekaragaman-hayati/, Accessed on October 17, 2016.

http://dri.ipb.ac.id/pelatihan-biosafety-dan-biosecurity-bagi-laboran/, Accessed on October 10, 2016.

http://www.menlh.go.id/pengesahan-cartagena-protocol-on-biosafety-to-the-convention-onbiological-diversity/, Accessed on October 6, 2016.

http://www.pelatihanlingkungan.com/wp-content/uploads/2015/05/Sambutan-Menteri-hari-

Kehati-2015.pdf, Accessed on October 10, 2016. 
